\title{
Survey of Orthodontists' Attitude and Experiences Regarding Miniscrew Implants in Baghdad City
}

\author{
Sami K. Al-Joubori ${ }^{1}$, Arwa S. Al-Chawoosh ${ }^{2}$ \\ ${ }^{1}$ Assistant Professor, Department of Orthodontics, College of Dentistry, University of Baghdad \\ ${ }^{2}$ Ministry of Health, Baghdad-Iraq
}

\begin{abstract}
Background: the aim of this study is to assess implant success rates, the predictability of placement techniques, or the management of risk factors for failure among sample of orthodontists in Baghdad. Materials and methods: Questionnaires were collected from certified orthodontist in private clinic and specialized center of ministry of health. This questionnaire was divided into six sections: practice characteristics, treatment planning, practice management, miniscrew placement, miniscrew complications and failures, annotated andBlinded data were extracted for statistical analysis. Statistical analyses were performed using the database of Excel and making percentage of each answer of all questions. Results: A questionnaire was given to 70 orthodontists working in Baghdad city. The questionnaire consisted of six parts, containing multiple-choice questions. Practice characteristics, treatment planning, practice management, miniscrew placement, miniscrew complications and failures were assessed. All statistical analyses were performed using Excel and taking percentage of each question. The overall response rate was (85\%). Most of the respondents (81\%) reported using miniscrews for orthodontics treatment. Indirect anchorage for space closure was the most commonly reported treatment indication (51\%), followed by Intrusion for anterior open bite (40\%) and Anterior en masse retraction (34\%), The most commonly reported biological, mechanical, or iatrogenic complications of mini-screw treatment most commonly were screw loosening (61\%), followed less commonly by soft-tissue overgrowth/irritation (61\%), and irritation caused by auxiliary springs (40\%). Conclusion: Most orthodontists in Baghdad uses Miniscrew Implant, most common uses of miniscrew implant are indirect anchorage for space closure, intrusion for anterior open bite and anterior en masse retraction, most common guide that helps in placement of miniscrew implant is OPG, most common complication for using miniscrew implant are miniscrew loosening, soft-tissue overgrowth/irritation and irritation caused by auxiliary springs.
\end{abstract}

Keywords: miniscrew implant, orthodontics, temporary anchorage devices

\section{Introduction}

Anchorage defined as 'Nature and degree of resistance to displacement offered by an anatomic unit when used for the purpose of effecting tooth movement'[1], Anchorage classified according to the site where the anchorage units as: Intraoral, extraoral and muscular [2].

Temporary anchorage devices (TADs)_implants/ minscrews are called as absolute anchorage without space loss due to movement of anchor teeth[2].

A dental implant is a biomedical device, which is usually composed of metallic alloy or an inert metal, which is placed within or on the osseous tissues[2].

Properties of miniscrewimplants: The metal or alloy used for their fabrication, the diameter of threaded portion, the length of the implant and the design of the head[3] Orthodontic miniscrew implants are made from stainless steel with a smooth surface to prevent complete osseointegration which complicates the removal process andto minimize the development of bone ingrowth and promoting soft tissue attachment at ordinary conditions[4$6]$.

Head Design: The most frequent design is the button like with a sphere or a double sphere like shape or a hexagonal shape, and the diameter isusually $0.8 \mathrm{~mm}$, this design is mostly used for direct anchorage. Further designs are a hook like or a bracket like which can be used both for direct and indirect anchorage.[3] Mini-implants are also available in different lengths[6].

Most miniscrew implants have a thread diameter ranging from 1.2 to $2.0 \mathrm{~mm}$ and a length from 4.0 to $12.0 \mathrm{~mm}$, although some of them are also available at lengths of 14 or even $21 \mathrm{~mm}[7,8]$

Miniscrews implant Used for: uprighting of molars, retraction of anterior teeth,open bite correction (archived by intruding posterior teeth: skeletal anchorage),mesiodistal tooth movement, distalization of 1 st and 2nd molars and Intrusion of teeth[2].

Contraindication: problematic healing, inadequate oral hygiene, compromised immune system, pathological bone quality, bleeding disorders, children with deciduous or early mixed dentition andheavy smoking $[9,10]$.

Complications: mini-implant failure, mini-implant fracture, damage of hard tissues, damage of soft tissues, damage to neurovascular tissues, Pain, perforation of nasal and maxillary sinus floors and Mini-implant migration[11].

\section{Materials and Methods}

Questionnaires were collected from certified orthodontist in private clinic and specialized center of ministry of health This recollection- and opinion-based questionnaire was divided into six sections: practice characteristics, treatment planning, practice management, miniscrew placement, 


\section{International Journal of Science and Research (IJSR) \\ ISSN (Online): 2319-7064}

Index Copernicus Value (2016): 79.57 | Impact Factor (2015): 6.391

miniscrew complications and failures.Annotated, blinded data were extracted for statistical analysis.

All statistical analyses were performed using the database of Excel and making percentage of each answer of all question

Q1-How many years have you practiced orthodontists?
A- $<2$ years.
B- 2-5 years.
C- 6-10 years.
D- 11-20 years.
E- >20 years.

Q2-Where is location of your practice?
A- Karkh.
B- Rasafa.

Q3-Active cases in practice?
A- $<100$.
B- 100-300.
C- $>300$.

Q4-Do you use miniscrew implant?
A- Yes. (if yes, go to Q6)
B- No.

Q5-Reasons for not using miniscrew implant?
A- Cost
B- Longer chairtime.
C- Need to administer LA.
D- Potential need to manage acute pain.
E- Lack of training. (Thank you for answering)

Q6-How many cases you treated with miniscrew implant?
A- 1-5 cases.
B- 6-10 cases.
C- 10-20 cases.
D- $>20$ cases.

Q7-The year when you first used miniscrew implant is

Q8-3 most common uses in treatment with miniscrew implant?
A- Molar protraction.
B- Indirect anchorage for space closure.
C- Intrusion of supererupted tooth .
D- Intrusion for anterior open bite.
E- Anterior en masse retraction.
F- Molar uprighting.
G- Intrusion for maxillary canine.
H- Molar distalization.
I- Traction on impacted canine.
J- Attachment of protraction facemask.

Q9-What do you request from patient to help in guidance of placement of miniscrew implant?
A- OPG.
B- CBCT.
C- Periapical.

Q10-Pain management during placement of miniscrew implant
A- Few drops of LA only.
B- Combination of topical and LA.
C- Only strong topical anesthesia.
D- Full nerve block.

Q11-Miniscrew implant system you use is
A- Morelli.
B- Dentos.
C- Dentaurum.
D- Ortho technology.
E- Hubit.
F- Friadent.
G- Others (

Q12-Most common Diameter of miniscrew implant you use is

A- $1.4 \mathrm{~mm}$

B- $1.6 \mathrm{~mm}$

C- Others (

Q13- Most common length of miniscrew implant you use is

A- $6 \mathrm{~mm}$.

B- $8 \mathrm{~mm}$.

C- $10 \mathrm{~mm}$.

D- Others (

Q14-Complication of miniscrew implant

\begin{tabular}{|c|l|l|l|l|}
\hline & Common & $\begin{array}{c}\text { Less } \\
\text { common }\end{array}$ & Rare & Never \\
\hline 1- Miniscrew loosening. & & & & \\
\hline 2- Soft tissue overgrowth/irritation. & & & & \\
\hline 3- Irritation from auxillary spring. & & & & \\
\hline 4- Aphthous ulcer. & & & & \\
\hline 5- Miniscrew drift/migration. & & & & \\
\hline 6- Interference with tooth movement. & & & & \\
\hline 7- Tooth sensitivity. & & & & \\
\hline 8- Infection. & & & & \\
\hline 9- Miniscrew fracture. & & & & \\
\hline 10- Slippage into periosteum. & & & & \\
\hline 11- Root damage. & & & & \\
\hline 12- Tooth ankylosis. & & & & \\
\hline 13- Sinus perforation. & & & & \\
\hline 14- Subcutaneous emphysema. & & & & \\
\hline
\end{tabular}

Q15-Are you satisfied with the usage miniscrew implant?
A- Yes.
B- No. (if no, why)
C-

\section{Results}

Practice Characteristics: In all, 60 of 70 certified orthodontists completed the survey, for an $(85.7 \%)$ response rate. Respondents were distributed among Karkh and Rasafa. Most respondents (58\%) had been in practice more than 5 years; only $(15 \%)$ have been in practice for less than two years. 


\section{International Journal of Science and Research (IJSR) \\ ISSN (Online): 2319-7064 \\ Index Copernicus Value (2016): 79.57 | Impact Factor (2015): 6.391}

Table 1: Describe percentage of results of each question

\begin{tabular}{|l|l|}
\hline Questions & $\%$ \\
\hline Q-Years in practice & $15.00 \%$ \\
\hline$<2$ years. & $26.66 \%$ \\
\hline $2-5$ years. & $23.33 \%$ \\
\hline 6-10 years. & $21.66 \%$ \\
\hline $11-20$ years. & $13.33 \%$ \\
\hline$>20$ years. & $60.00 \%$ \\
\hline Q-Location of practice \\
\hline Karkh & $41.66 \%$ \\
\hline Rasafa & $36.66 \%$ \\
\hline Q-Active cases in practice \\
\hline$<100$. & $31.66 \%$ \\
\hline $100-300$. & $31.66 \%$ \\
\hline$>300$ &
\end{tabular}

Miniscrew Experience: $(81 \%)$ of the orthodontists reported using miniscrews for orthodontics treatment, experience levels varied widely among the them, no clinician reported using miniscrews before 2005, and four had begun placing screws as recently as 2016, (32\%) reported having placed more than 20 miniscrews, $(2 \%)$ of them reported placing more than 400 miniscrews, the most common reason cited for not using miniscrews was the lack of training (82\%), other factors included longer chairtime (9\%) and cost $(9 \%)$, the most commonly reported treatment indication was indirect anchorage for space closure (51\%), followed by Intrusion for anterior open bite (40\%) and Anterior en masse retraction $(34 \%)$, a panoramic radiograph was the most requested or readily available diagnostic tool used to guide miniscrew placement $(69 \%)$, for pain management, most respondents $(71 \%)$ reported using few drops of LA only; $(26 \%)$ said they used Combination of topical and LA, while (2\%) administered only a strong topical agent, the three preferred miniscrew systems were those manufactured by Dentos, Dentaurum, ortho technology and Hubit, while (14\%) reported using other systems, the most common diameters were $1.6 \mathrm{~mm}$ - and $1.4 \mathrm{~mm}$, and the mostcommon length was $8 \mathrm{~mm}$.

Most respondents (98\%) were satisfied with the performance of miniscrews in their practices. Only (2\%) of the respondent were dissatisfied with it
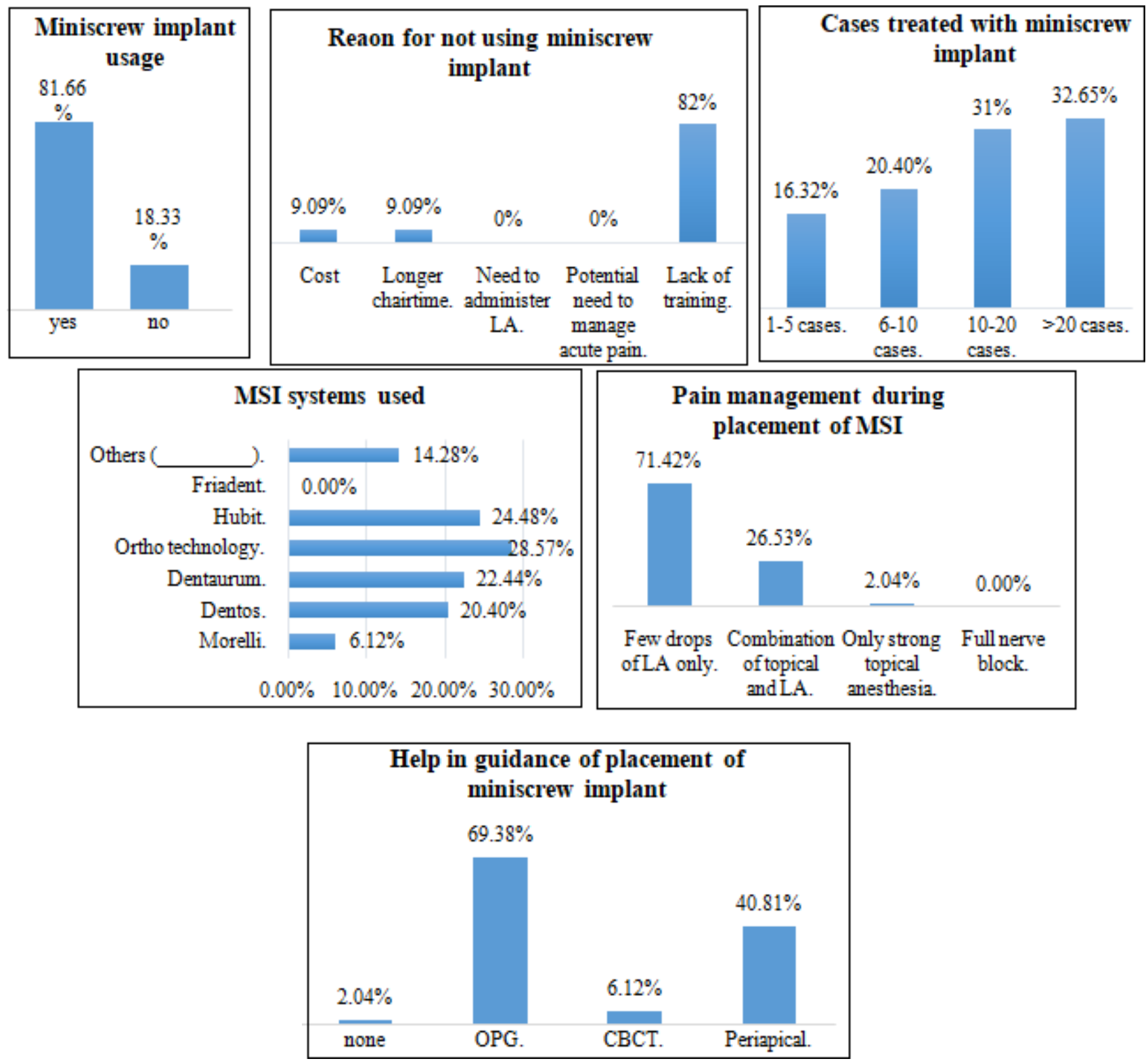

Volume 6 Issue 12, December 2017 www.ijsr.net 


\section{International Journal of Science and Research (IJSR) \\ ISSN (Online): 2319-7064}

Index Copernicus Value (2016): 79.57 | Impact Factor (2015): 6.391

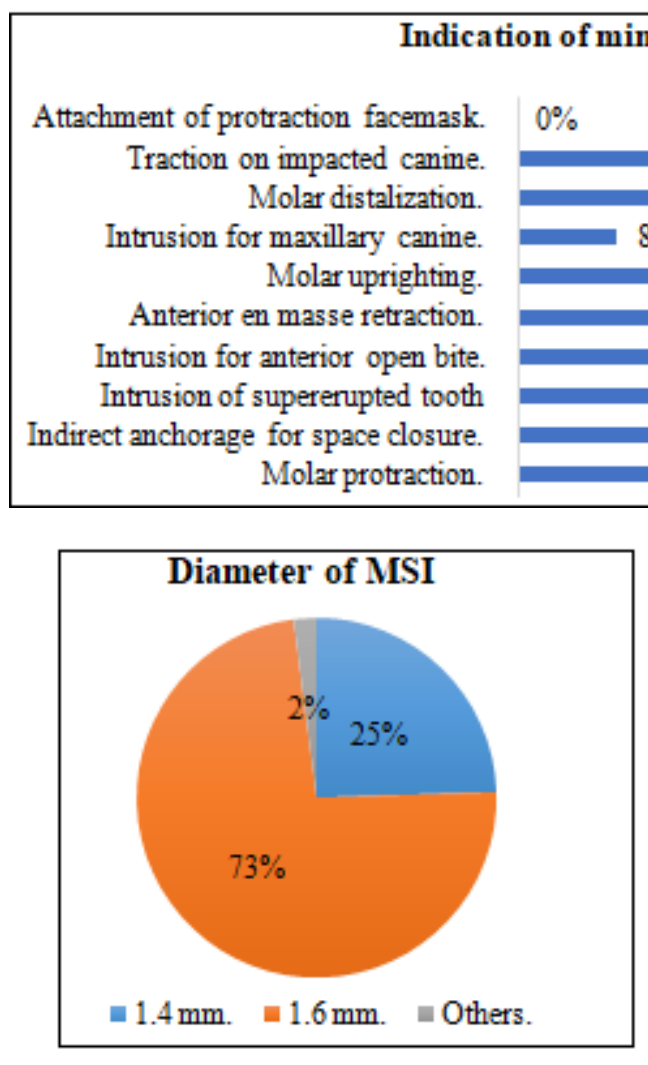

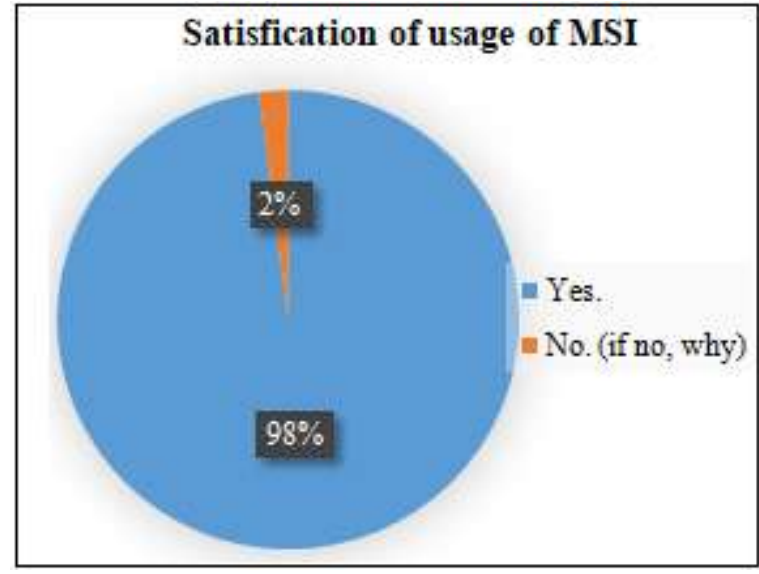

Miniscrew Complications: The most commonly reported biological, mechanical, or iatrogenic complications of miniscrew treatment were screw loosening (61\%), soft-tissue overgrowth/irritation (61\%), and irritation caused by auxiliary springs (40\%). There were almost no reported cases of tooth ankylosis, sinus perforation, or subcutaneous emphysema.

Table 2: Describe Percentages of orthodontists reporting various biological or mechanical complications of miniscrew implants

\begin{tabular}{|l|c|c|c|c|}
\hline $\begin{array}{c}\text { Complication of miniscrew } \\
\text { implant }\end{array}$ & Common & $\begin{array}{c}\text { Less } \\
\text { common }\end{array}$ & Rare & Never \\
\hline 1- Miniscrew loosening. & $61.22 \%$ & $26.53 \%$ & $10.20 \%$ & $02.04 \%$ \\
\hline $\begin{array}{l}\text { 2- Soft tissue } \\
\text { overgrowth/irritation. }\end{array}$ & $12.24 \%$ & $61.22 \%$ & $22.44 \%$ & $04.08 \%$ \\
\hline $\begin{array}{l}\text { 3- Irritation from auxillary } \\
\text { spring. }\end{array}$ & $02.04 \%$ & $40.81 \%$ & $34.69 \%$ & $22.44 \%$ \\
\hline 4- Aphthous ulcer. & $10.20 \%$ & $22.44 \%$ & $38.77 \%$ & $28.57 \%$ \\
\hline 5- Miniscrew drift/migration. & $02.04 \%$ & $36.73 \%$ & $44.89 \%$ & $16.32 \%$ \\
\hline 6- Interference with tooth & $02.04 \%$ & $12.24 \%$ & $51.02 \%$ & $34.69 \%$ \\
\hline
\end{tabular}

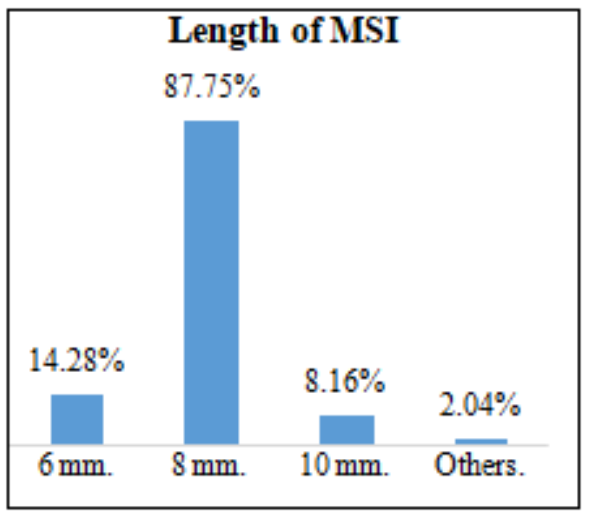

\begin{tabular}{|l|l|l|l|l|}
\hline movement. & & & & \\
\hline 7- Tooth sensitivity. & $00.00 \%$ & $14.28 \%$ & $36.73 \%$ & $48.97 \%$ \\
\hline 8- Infection. & $08.16 \%$ & $12.24 \%$ & $42.85 \%$ & $36.73 \%$ \\
\hline 9- Miniscrew fracture. & $00.00 \%$ & $08.16 \%$ & $46.93 \%$ & $44.89 \%$ \\
\hline 10- Slippage into periosteum. & $00.00 \%$ & $04.08 \%$ & $42.85 \%$ & $53.06 \%$ \\
\hline 11- Root damage. & $00.00 \%$ & $04.08 \%$ & $32.65 \%$ & $63.26 \%$ \\
\hline 12- Tooth ankylosis. & $00.00 \%$ & $02.04 \%$ & $16.32 \%$ & $81.63 \%$ \\
\hline 13- Sinus perforation. & $00.00 \%$ & $02.04 \%$ & $16.32 \%$ & $81.63 \%$ \\
\hline $\begin{array}{l}\text { 14- Subcutaneous } \\
\text { emphysema. }\end{array}$ & $00.00 \%$ & $00.00 \%$ & $14.28 \%$ & $85.71 \%$ \\
\hline
\end{tabular}

\section{Discussion}

Results of this study are comparable with one large-scale published survey of orthodontists' experiences with miniscrews, this study had a higher response rate and potential number of participants, whereas Journal of clinical orthodontics (JCO) e-mailed a secure link to a web-based survey, in this study the questionnaires were distributed to private clinic and specialized center of ministry of health, the proportion of respondents placing miniscrews in this study $(81 \%)$ was close to that reported in the JCO survey, this study respondents and the JCO respondents agreed regarding the use of diagnostic tools, anesthesia protocols. A panoramic radiograph was the primary placement guide in both surveys[12].

The most common miniscrew treatment indications differed slightly among this survey members and the JCO network respondent. Although space closure and intrusion of anterior open bite were the most commonly reported indications in both this survey members and respondents to the JCO survey were more likely to use miniscrews for molar protraction, by comparison, the most common indication for miniscrew placement in previous studies has been maxillary molar protraction, followed by space closure and intrusion

\section{Volume 6 Issue 12, December 2017}




\section{International Journal of Science and Research (IJSR) \\ ISSN (Online): 2319-7064}

Index Copernicus Value (2016): 79.57 | Impact Factor (2015): 6.391

of supererupted tooth, with other types of treatment in a clear minority[12].

Two recent systematic reviews have suggested that implant diameters of less than $1.3 \mathrm{~mm}$ or greater than $2 \mathrm{~mm}$, as well as lengths of less than $8 \mathrm{~mm}$, are more susceptible to failure $[13,14]$.

\section{References}

[1] Graber TM (Thomas M. Orthodontics; principles and practice. Saunders; 1972.953 p.

[2] Singh G. Textbook of Orthodontics. 2015. p. 734.

[3] Jasoria G, Shamim W, Rathore S, Kalra A, Manchanda M, Jaggi N. Miniscrew implants as temporary anchorage devices in orthodontics: A comprehensive review. J Contemp Dent Pract. 2013;14(5):993-9.

[4] Carano A, Velo S, Incorvati C PP. Clinical applications of the miniscrew- anchorage system (M.A.S.) in the maxillary alveolar bone. Prog Orthod. 2004;5(1):212-235.

[5] Melsen B, Costa A. Immediate loading of implants used for orthodontic anchorage. ClinOrthod Res. 2000 Feb;3(1):23-8.

[6] Deguchi T, Takano-Yamamoto T, Kanomi R, Hartsfield JK, Roberts WE, Garetto LP. The use of small titanium screws for orthodontic anchorage. J Dent Res. 2003 May;82(5):377-81.

[7] Maino BG, Mura P, Bednar J. Miniscrew implants: The Spider Screw anchorage system. SeminOrthod. 2005 Mar;11(1):40-6.

[8] Kyung H-M, Park H-S, Bae S-M, Sung J-H, Kim I-B. Development of orthodontic micro-implants for intraoral anchorage. J ClinOrthod. 2003 Jun;37(6):321-8; quiz 314.

[9] Chen Y-J, Chang H-H, Huang C-Y, Hung H-C, Lai $\mathrm{EH}-\mathrm{H}$, Yao C-CJ. A retrospective analysis of the failure rate of three different orthodontic skeletal anchorage systems. Clin Oral Implants Res. 2007 Dec;18(6):768-75.

[10] Cornelius C-P, Ehrenfeld M. The Use of MMF Screws: Surgical Technique, Indications, Contraindications, and Common Problems in Review of the Literature. Craniomaxillofacial Trauma Reconstr. 2010 Jun;3(2):055-80.

[11] Cousley RRJ. The orthodontic mini-implant clinical handbook. John Wiley \& Sons Ltd; 2013.

[12] Hyde JD, King GJ, Greenlee GM, Spiekerman C, Huang GJ. Survey of orthodontists' attitudes and experiences regarding miniscrew implants. J ClinOrthod. 2010 Aug;44(8):481-6.

[13] Chen Y, Kyung HM, Zhao WT, Yu WJ. Critical factors for the success of orthodontic mini-implants: A systematic review. Am J OrthodDentofacOrthop. 2009 Mar;135(3):284-91.

[14] Reynders R, Ronchi L, Bipat S. Mini-implants in orthodontics: A systematic review of the literature. Am J OrthodDentofacOrthop. 2009 May;135(5):564.e1-564.e19. 